\title{
Histochemical study on the apocrine sweat gland in the circumanal region of cattle
}

\author{
By \\ Norio Ato \\ Department of Anatomy, School of Medicine, \\ Keio University, Tokyo, Japan \\ (Director: Prof. Dr. T. Taniguchi)
}

\section{Introduction}

The author (1961) reported in the previous paper, that though glandular cells of the cattle sweat glands were generally flat, those in the circumanal region were generally cuboidal or cylindrical in their shape, and only a few flat cells were encountered, further that the apical cytoplasm of the glandular cells is often positive for PAS reaction. In the present study, the cuboidal and cylindrical glandular cells and the luminal contents of the sweat gland in the circumanal region of cattle were investigated from the histochemical view-point.

\section{Material and Method}

Three healthy adult cows were used as experimental animals. Skin specimens were taken from the circumanal region of the cattle immediately after the cattle were sacrified. These materials were excised within $5 \mathrm{~cm}$ from the transitional portion from the hairy skin to the mucous membrane. The tissues were fixed in absolute alcohol and in Zenker-formalin solution, embedded in paraffin and sectioned serially at $5 \mu$. These sections were stained with allochrome staining ( $\mathrm{L}$ i 11 i e, 1954), pyronine-methylgreen staining and toluidin blue staining. For the pyronine-methylgreen staining, Unna's solution, buffered with McIlvaine buffer to $\mathrm{pH} 4.8$, was used. For the toluidin blue staining, the solution was $0.05 \%$ in its concentration and was buffered with McIlvaine buffer to $\mathrm{pH}$. $2.5,4.0$ and 5.6 . 
The sections were stained with toluidin blue after the incubation in $1 \mathrm{~N}$ hydrochloric acid solution at $37^{\circ} \mathrm{C}$ for three hours. Moreover, employing $\mathrm{De} \mathrm{m}$ p s y's method (1950), the sections were stained with toluidin blue after the oxidation with $1 \%$ periodic acid solution at $37^{\circ} \mathrm{C}$ for one hour.

\section{Original Findings}

Glandular cells arrange themselves in one layer. Generally, they are cuboidal in their shape, but sometimes cylindrical cells that possess a distinct secretory process are encountered.

With allochrome staining, apical cytoplasm of the glandular cells is frequently stained in diffuse red color. Sometimes the cytoplasm extending from the supra-nuclear portion to the apical portion is also diffusely stained in red color. The infra-nuclear and supra-nuclear portions that are not stained in red color, present greenish yellow coloration. Sometimes a few coarse granules with red coloration are observable in the basal cytoplasm. This is probably attributable to the PAS positive reaction of the brown pigment granules. The nucleus of the glandular cells shows yellow or yellowish green coloration. The luminal contents show a reticular appearance and are intensively stained in red color. In several glandular cells the whole cytoplasm is diffusely stained in red. These red colored portions are in accordance with the PAS positive portions. This stainability is not diminished after the diastase digestion.

Using pyronine-methylgreen staining, the basal cytoplasm of the glandular cells generally shows a fine network and is stained somewhat intensively in red color. The supra-nuclear and apical cytoplasm show a weak stainability. However, in some glandular cells the cytoplasm of these portions shows a fine network and is intensively stained in red color. The stainability of secretory process is generally very weak. The apex of the secretory process is unstainable in zonal form, and shows feeble brown coloration. But, a few secretory processes which are diffusely stained in red color, are observable. The nucleus of the glandular cells is stained in greenish blue. Occasionally, the luminal site of the nuclear membrane shows a somewhat intensive red coloration and a cord-like stainability which are red in color is recognizable towards the apical cytoplasm. The luminal contents are not stained 
with a pyronine-methylgreen staining method and show feeble brown coloration.

Employing toluidin blue staining ( $\mathrm{pH}$ 5.6), the cytoplasm of the glandular cells is stained in blue with slightly purplish color. The apical cytoplasm is generally stained more intensively than the basal and perinuclear cytoplasm. Though the coarse granules are hardly observable in the cytoplasm, sometimes fine granules with bluish purple coloration are encountered in the supra-nuclear cytoplasm. The nucleus of the glandular cells shows deep blue color and the nucleolus is stained in deeper blue color than the former. The luminal contents present purplish red metachromasia and this coloration is different from any other portions of the glandular cells.

Using toluidin blue staining ( $\mathrm{pH} \mathrm{4.0),} \mathrm{the} \mathrm{stainability} \mathrm{of} \mathrm{the}$ glandular cells is weaker than that stained with the solution of pH 5.6. The cytoplasm is tinged in blue with slightly purplish color. The apical cytoplasm, in general, shows a somewhat intensive stainability as compared with the perinuclear and basal cytoplasm. The luminal contents present purplish red metachromasia as well as those stained with the solution at $\mathrm{pH}$ 5.6.

Using toluidin blue staining ( $\mathrm{pH} \mathrm{2.5),} \mathrm{the} \mathrm{stainability} \mathrm{of} \mathrm{the}$ glandular cells is very feeble. Cytoplasma is stained in feeble light blue color. The nucleus shows feeble blue coloration and the nucleolus does blue coloration. The stainability of the luminal contents is very weak, but purplish red metachromasia is observable in the luminal contents.

When the sections are stained with toluidin blue (pH 5.6) after the incubation in $1 \mathrm{~N}$ hydrochloric acid solution at $37^{\circ} \mathrm{C}$ for three hours, the stainability of the glandular cells is distinctly diminished. The cytoplasm is diffusely and feebly stained in light blue, but sometimes the apical cytoplasm is stained somewhat intensively. The nucleus is feebly stained in blue and the nucleolus is stained blue. Occasionally the glandular cells, the whole cytoplasm of which is stained somewhat intensively blue, are recognizable. These cells are thought to correspond to the cells, the cytoplasm of which is stained diffusely red with allochrome staining. The luminal contents present, as well as those, not to be treated preliminary, purplish red metachromasia, but the intensity of their stainability is somewhat decreased.

When the tissue sections are stained with toluidin blue $(\mathrm{pH}$ 5.6) 
after the incubation in $1 \%$ periodic acid solution at $37^{\circ} \mathrm{C}$ for one hour, the stainability of the glandular cells increases distinctly. The cytoplasm shows deep purplish blue coloration. The apical cytoplasm, generally, shows more intensive coloration than the perinuclear and basal cytoplasm. Purplish red metachromasia, almostly the same coloration as the luminal contents, are frequently recognizable at the apex of the secretory process. The nucleus presents a deep blue coloration and the nucleolus shows a deeper blue coloration. The luminal contents show purplish red metachromasia.

\section{Discussion}

As regards the form and the secretion process of the human axillary apocrine sweat gland, $M$ i n a $m$ it a $n$ i (1941), I t o (1949) and others have reported and, besides, histochemical investigations have been made by Montag na (1951), Yasuda (1959), Y a sui (1960) and others. Comparing the findings on the sweat gland of the cattle with the above mentioned investigations, the so-called secretory granules are fine in the cattle, namely, such coarse granules as in the human axillary apocrine sweat gland are not observable in the cattle sweat gland. Moreover, employing PAS staining, the apical cytoplasm is diffusely stained red, but not any granular structures are observable. That is, in the cattle apocrine sweat gland, being different from the human apocrine sweat gland, PAS positive substances do not form coarse granules, but they are diffusely and homogeneously distributed in the apical portion of the cell; then they are probably eliminated into the lumen. Apical cytoplasm of the glandular cells as well as the luminal contents present PAS positive reaction, and this PAS positive reaction is not diminished after the diastase digestion. It is thought that the apical cytoplasm contains similar substances to the luminal one. However, comparing the stainability of the apical cytoplasm with that of the luminal contents, some apreciable differences are observed as shown in table 1.

By means of allochrome staining, the luminal contents and apical cytoplasm of some glandular cells are stained in red color. Using pyronine-methylgreen staining, however, the luminal contents are unstainable, on the other hand the apical cytoplasm generally shows pyroninophilic characters. These facts mean probably, that 
Table 1. Stainability of luminal contents and apical cytoplasm.

\begin{tabular}{|c|c|c|c|}
\hline & & Luminal contents & Apical cytoplasm \\
\hline \multicolumn{2}{|c|}{ Allochrome staining } & Red & Red \\
\hline \multicolumn{2}{|c|}{ Pyronine-methylgreen staining } & Unstainable & Weakly pyroninophilic \\
\hline \multirow{5}{*}{$\begin{array}{l}\text { Toluidin-blue } \\
\text { staining }\end{array}$} & pH 5.6 & Purplish red & Blue (slightly purple) \\
\hline & $\mathrm{pH} 4.0$ & Purplish red & Blue (slightly purple) \\
\hline & $\mathrm{pH} 2.5$ & Feeble purplish red & Feeble light blue \\
\hline & $\begin{array}{l}\text { After the treatment } \\
\text { with } 1 \mathrm{~N} \mathbf{H C l}\end{array}$ & Purplish red & Feeble blue \\
\hline & $\begin{array}{l}\text { After the treatment } \\
\text { with periodic acid }\end{array}$ & Purplish red & Purplish red \\
\hline
\end{tabular}

the luminal contents do not contain ribonucleic acid but the apical cytoplasm contains RNA in addition to the PAS positive substances. However, a zonal unstainable portion with pyronine is observable at the apex of the secretory process. In such portion the PAS positive substances locate at the different position from RNA.

According to Montag na (1951), the glandular cells of the sweat gland in the human mons pubis show lilac coloration with toluidin blue staining at $\mathrm{pH}$ 4.0. At $\mathrm{pH}$ 5.0, the apical cytoplasm shows an intermediate coloration between the metachromasia and orthochromasia. At higher pH levels, glandular cells stain so intensely that metachromasia is masked. In the authors observation on the cattle sweat gland, the apical cytoplasm is stained in blue with slightly purplish metachromasia by toluidin blue staining at $\mathrm{pH} 4.0$ and 5.6, but not any purplish red metachromasia, that is observable in the luminal contents, is encountered in the apical cytoplasm.

Employing toluidin blne staining after the elimination of RNA with iN hydrochloric acid, the stainability of the cytoplasm is distinctly diminished, showing feeble blue. The luminal contents show purplish red metachromasia. Namely, it is assumable that RNA in the glandular cells is destroyed by the preliminary treatment with iN hydrochloric acid for three hours, but the PAS positive substances in the luminal contents are not destroyed. Presumably the PAS positive substances in the apical cytoplasm also remain undestroyed, but here distinct metachromasia as seen in the luminal contents is not observable.

It is said, that coloration of the metachromasia depends on the 
correlative density of dye and stainable substance, existence of the electrolyte, and various elements in the tissue. There is a difference of coloration of metachromasia between the PAS positive substances in the glandular cells and that in the luminal contents. It is thought, that the PAS positive substances in the glandular cells exist together with the other cellular elements, so that the PAS positive substances in the glandular cells are different from the PAS positive substance in the luminal contents in its stainable condition. Therefor it can not be decided, whether or not the PAS positive substances in both luminal contents and glandular cells are different from each other in their chemical composition.

De m p s y (1950) recognized that the stainability by toluidin blue increased in epidermis and in hair follicle after the preliminary treatment with periodic acid. And, he reported that this increase in the stainability was probably attributable to the next reason that sulfide and sulfhydryl in the tissue were oxidized to sulfonic acid and showed an intensive basophile. In the cattle sweat glands, it is presumed that some substances like sulfide or sulfhydryl are contained in the cytoplasm, considering from the results, that the stainability to toluidin blue is intensified distinctly after the preliminary treatment with periodic acid.

The luminal contents are PAS positive and show metachromasia by toluidin blue staining method. Metachromasia are not changed with the preliminary treatment with $1 \mathrm{~N}$ hydrochloric acid and the PAS positive reaction also is not changed, even after the diastase digestion. From these points it is thought, that the luminal contents contain mucopolysaccharide. When toluidin blue staining at $\mathrm{pH} 2.5,4.0$ and 5.6 is carried out in accordance with $\mathrm{O}$ on $\mathrm{o}$, $\mathrm{Notsuke}$ and $\mathrm{Kaw}$ a i's technique, metachromasia is always observable. Namely, hyaluronic acid is not recognizable in the luminal contents.

Y a s u a (1959) reported on the apocrine sweat gland in the human axilla, the non typical cells, which, similar to the so-called clear cells in the eccrine sweat gland, contained glycogen, the whole cytoplasm of which showed the PAS positive reaction. He insisted further that, these non-typical cells might be changed from the myoepithelial cells. In the sweat gland of cattle, sometimes the glandular cells, in which the whole cytoplasm shows PAS positive reaction, are observed. These cells probably contain a good deal of mucopolysaccharide. Differing from the non-typical cells named 
by $\mathrm{Y}$ as uda, these cells may be the glandular cells which have undergone mucous degeneration.

\section{Summary}

Histochemical investigation on the apocrine sweat gland in the circumanal region of the cattle was carried out employing allochrome staining, pyronine-methylgreen staining, toluidin blue staining at $\mathrm{pH}$ 2.5. 4.0 and 5.6, and toluidin blue staining after the preliminary treatment with $1 \mathrm{~N}$ hydrochloric acid and $1 \%$ periodic acid respectively. Stainabilities of both glandular cells and luminal contents were observed.

1) By means of the above mentioned staining, any coarse granules that correspond to the so-called secretory granules were not recognized.

2) The luminal contents were PAS positive and they showed metachromasia with toluidin blue staining and besides, this metachromasia was not diminished even by the preliminary treatment with $1 \mathrm{~N}$ hydrochloric acid. Accordingly, the luminal contents might be considered to contain mucopolysaccharide but no glycogen. Ribonucleic acid and hyaluronic acid were not demonstrated.

3) The cytoplasm of the glandular cells was pyroninophilic and it possibly contained RNA. Moreover, the apical cytoplasm showed a PAS positive reaction, and probably contained similar mucopolysaccharide to that in the luminal contents. However, clearly distinct metachromasia, as seen in the luminal contents, was not recognized in the apical cytoplasm with toluidin blue staining.

4) With toluidin blue staining followed by the preliminary treatment with $1 \%$ periodic acid, the stainability of the glandular cells intensified, and the apex of the secretory process showed purple red metachromasia, and this coloration was similar to that in the luminal contents.

5) A few glandular cells that were possibly provided with a good deal of mucopolysaccharide throughout the cytoplasm was encountered.

\section{Acknowledgement}

The author wished to acknowledge his great indebtedness to Prof. Dr. T, Taniguchi for his kind criticism and helpful 
guidance during the course of this work.

\section{Literature}

1) A t o, N.: Histochemical investigation on the sweat gland of cattle. Especially on the distribution of protein, mucopolysaccharide, lipid and phosphatases. Okajimas Fol. anat. jap., Bd. 36, ss. 429-450, 1961.

2) Dem psey, E.W., M. Sing er and G.B.W is locki: The increased basophilia of tissue protein after oxidation with periodic acid. Stain technology, Vol. 25, pp. 73-80, 1950.

3) It o, T.: Histology and cytology of sweet gland. Igakuno-shinpo, Tokyo, 6, p. 106, 1949. (in Japanese)

4) Lilli e, R.D.: Histopathologic technic and practical histochemistry. Blakiston Co., New York, 1954.

5) M in a m it a n i, K.: Zytologische und hystologische Untersuchungen der Schweissđrüsen in menschlicher Achselhaut. Über das Vorkommen der besonderen Formen der apokrinen und ekkrinen Schweissdrüsen in der Achselhaut von Japanern. Okajimas Fol. anat. jap., Bd. 20, ss. 563-591, 1941-a.

6) Montag na, W., H.B. Ch a se and H.P. Melaragno: Histology and cytology of human skin. I. Metachromasia in the mons pubis. Jour. National Cancer Institut., Vol. 12, pp. 591-597, 1951.

7) Ok a moto, K., M. Ued a and T. M a eda : Microscopic histochemistry. 2nd Ed., Igaku-shoin, Tokyo., 1958. (in Japanese)

8) Oono, K., I. Notsuke and T. Kawai: The method to demonstratc acid mucopolysaccharide. Medicine and Bilogy. Vol. 19, p. 326, 1951. (in Japanese).

9) Yasu da, K. On the non-typical cell in the axillary sweat gland. Okajimas Fol. anat. jap., Bd. 33, ss. 353-372, 1959.

10) Yasui, I.: On the granules in the axillary apocrine sweat glands of the Japanease children. Okajimas Fol. anat. jap., Bd. 36, ss. 309-328, 1960.

\section{Explanation of figures}

Fig. 1. PAS staining. The luminal contents and the apical cytoplasm of the glandular cells are stained red.

Fig. 2. Allochrome staining. A glandular cell, in which the whole cytoplasma is stained red is recognized.

Fig. 3. Pyronine-methylgreen staining.

Fig. 4. Toluidin blue staining ( $\mathrm{pH}$ 5.6).

Fig. 5. Toluidin blue staining after the preliminary treatment with $1 \mathrm{~N}$ hydrochloric acid. The luminal contents show metachromasia. The stainability of the cytoplasm of the glandular cells is diminished. The cells, in which the whole cytoplasm is stained somewhat intensively blue is recongnized.

Fig. 6. Toluidin blue staining followed by the preliminary treatment with $1 \%$ periodic acid. The cytoplasm of the glandular cells increase its stainability. The apical portions of the glandular cells present metachromasia with similar coloration to that in the luminal contents. 
Plate I
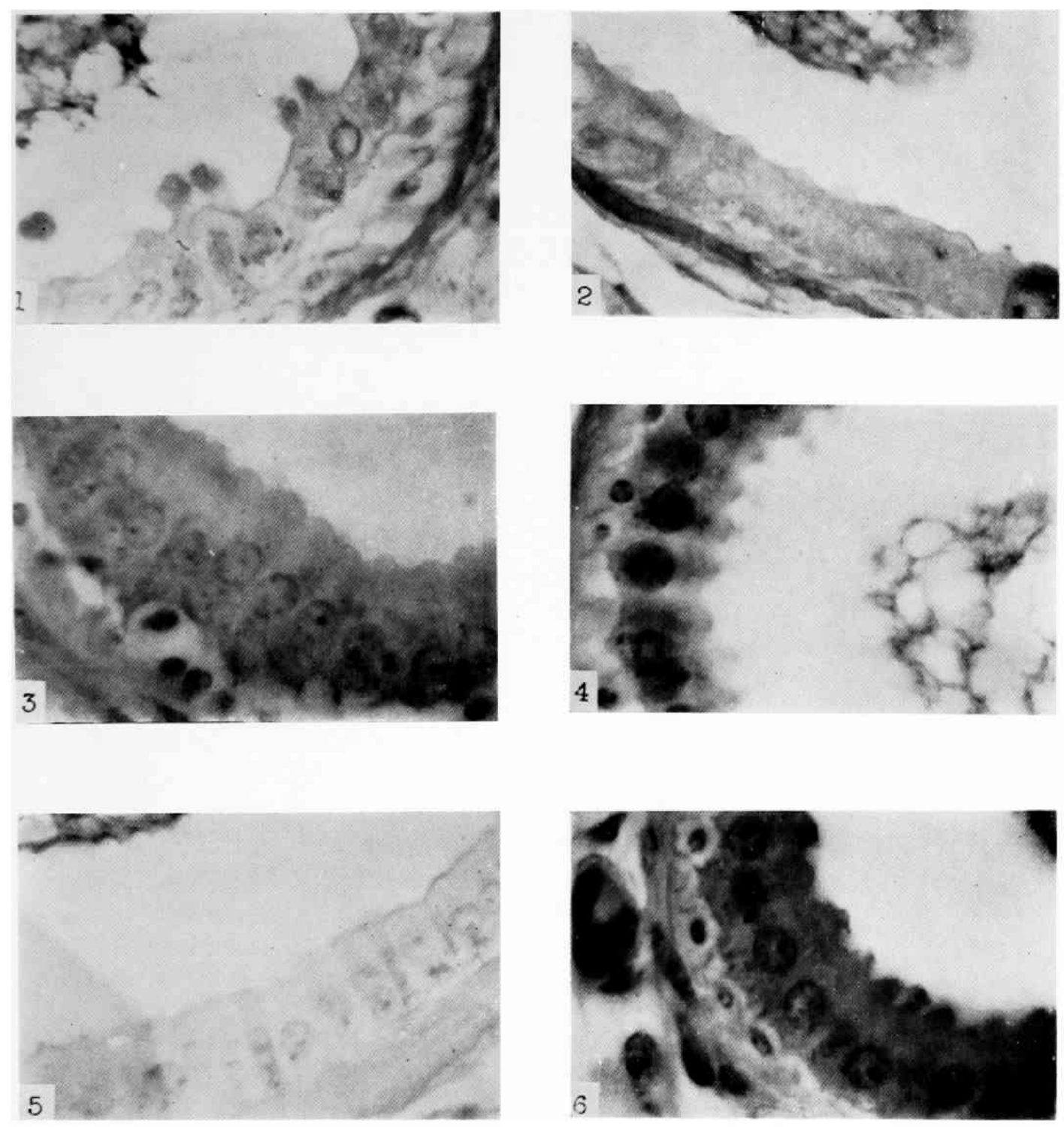

\section{N. Ato}

